\title{
IMPLIKASI METODE MENGAJAR BAGI GURU PENDIDIKAN AGAMA KRISTEN
}

\author{
Hendrik Legi \\ Sekolah Tinggi Agama Kristen \\ (STAK) Diaspora Wamena, Papua \\ Hendriklegi83@gmail.com
}

\begin{abstract}
The task of a Christian Religious Education teacher is not just to teach and prepare teaching materials, but a teacher is required to be able to create active, creative learning interactions and be able to design fun learning. Christian religious education teachers are not only tasked with transferring factual and conceptual knowledge to their students but Christian religious education teachers must think about how students can receive messages in their teaching and learning process. One of the reasons the learning process did not go as expected by the teacher was due to the inaccurate selection of teaching methods in the teaching and learning process. It cannot be denied that teaching methods also affect the ability of students to absorb learning material. Learning will be fun if the Christian Religious Education teacher chooses and uses various teaching methods in their teaching assignments. The research approach used is a descriptive approach, namely methods and research procedures that are Research Library by utilizing information sources from books and journals. This study aims to describe the implications of Christian religious education teaching methods for Christian religion teachers.

Keywords: Christian Religion Teachers, Christian Religious Education, Teaching Methods.
\end{abstract}

\begin{abstract}
ABSTRAK
Tugas seorang guru Pendidikan Agama Kristen bukan hanya sekadar mengajar serta menyiapkan materi ajar, melainkan seorang guru dituntut untuk dapat menciptakan interaksi pembelajaran yang aktif, kreatif serta dapat mendisain pembelajaran yang menyenangkan. Guru pendidikan agama Kristen tidak hanya bertugas memindahkan pengetahuan faktual dan konseptual kepada peserta didiknya tetapi guru pendidikan agama Kristen harus memikirkan bagaimana peserta didik dapat menerima pesan dalam proses belajar mengajarnya. Salah satu penyebab proses pembelajaran tidak berjalan sesuai dengan yang diharapkan oleh guru karena pemilihan metode mengajar yang kurang tepat dalam proses belajar mengajar Belajar dari Sang guru Agung, Tuhan Yesus Kristus selalu menggunakan metode yang berbeda-beda ketika mengajar para murid maupun orang banyak. Tidak dapat dipungkiri bahwa metode mengajar ikut memengaruhi kemampuan peserta didik dalam menyerap materi pembelajaran. Pembelajaran akan menjadi menyenangkan apabila guru Pendidikan Agama Kristen memilih
\end{abstract}


dan menggunakan metode mengajar yang variatif dalam tugas mengajarnya. Pendekatan penelitian yang digunakan adalah metode pendekatan deskriptif, yaitu metode dan prosedur penelitian yang bersifat Research Library dengan memanfaatkan sumber-sumber informasi dari buku maupun jurnal. Penelitian ini bertujuan mendeskripsikan implikasi metode mengajar pendidikan agama Kristen bagi guru Agama Kristen.

Kata kunci: Guru Agama Kristen, Pendidikan Agama Kristen, Metode Mengajar.

\section{PENDAHULUAN}

Peningkatan mutu pendidikan adalah salah satu upaya dalam rangka meningkatkan sumber daya manusia di bidang pendidikan nasional. Berbagai cara telah dilakukan oleh pemerintah agar tercapai sasaran pendidikan antara lain dengan penyempurnaan kurikulum, pemerataan guru-guru, juga pengadaan sarana prasarana yang memadai. Hal ini dimaksudkan untuk menunjang kebijakan pemerintah dalam rangka meningkatkan mutu pendidikan. Namun dalam menunjang program peningkatan sumber daya manusia di bidang pendidikan tersebut ada banyak kendala yang dialami oleh guru.

Salah satu masalah yang dihadapi oleh guru yaitu masalah pengelolaan kelas. Pengelolaan kelas adalah merupakan masalah yang tidak pernah absen dari agenda kegiatan guru (Zain, 2006, p. 72). Pada dasarnya guru menginginkan agar materi pelajaran yang disampaikan kepada peserta didik dapat dipahami secara tuntas oleh peserta didik. Sementara harapan tersebut bukanlah suatu perkara yang dianggap mudah, karena setiap peserta didik memiliki karakteristik yang berbeda baik dari segi minat, potensi kecerdasan dan usaha siswa itu sendiri. Dari keberagaman pribadi yang dimiliki oleh peserta didik tersebut, sebagai guru dituntut mampu memberikan, mencari solusi dan menggunakan strategi yang tepat sehingga yang dirumuskan dalam setiap rencana pembelajaran dapat tercapai. Oleh karena itu guru memerlukan suatu pemahaman yang komprehensif dan utuh mengenai cara atau metode untuk mendekati peserta didik, sehingga dapat terciptanya proses dan interaksi mengajar dan belajar yang baik. Karena itu dalam suatu proses pembelajaran di kelas, seorang guru kerap kali dituntut untuk melakukan pendekatan tertentu terhadap semua peserta didik. Oleh karenanya metode mengajar mempunyai andil yang cukup besar dalam proses mengajar dan belajar.

Pendidikan Agama Kristen (PAK) sebagai bagian dari hakikat pendidikan juga diperhadapkan dengan masalah metode mengajar. Seorang guru PAK harus memahami beragam metode mengajar sebagai salah satu komponen yang mendukung keberhasilan

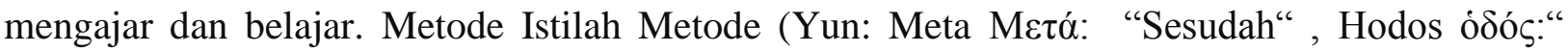
Cara, Jalan") ada banyak pandangan dari toko pendidikan kristen mengenai metode mengajar yang dapat dipilih dan diterapkan oleh guru. Misalnya, K.O. Gangel memahami metode mengajar dari jenis dan bentuk komunikasi interaksi guru dengan peserta didiknya (Sidjabat, 1993, p. 231). Mengajar yang benar dan relevan akan dapat menolong siswa menangkap pelajaran secara optimal dalam belajar dan dapat memberi jawaban terhadap rasa ingin tau mereka. Karena itu dibutuhkan suatu pengembangan metode mengajar yang bertujuan untuk menciptakan proses pembelajaran yang memungkinkan peserta didik dapat belajar secara aktif dan menyenangkan sehingga peserta didik dapat meraih keberhasilan dan prestasi yang optimal (Anurrahman, 2009, p. 140).

Sri Narwanti mengungkapkan tidak dapat dipungkiri bahwa peranan guru penting dalam proses pembelajaran. Namun pada saat ini telah berkembang dalam ilmu pendidikan, yaitu pola 
pendidikan yang berorientasi pada siswa (Somandi, 2012, p. 73). Pada umumnya memang kecenderungan pendidikan masih didominasi oleh pemahaman bahwa pengetahuan adalah merupakan perangkat informasi dan fakta-fakta yang harus dihafal melalui pengajaran para guru. Dalam hal ini kelas masih berfokus pada guru sebagai sumber utama pengetahuan, sehingga kelas menjadi tidak produktif karena metode ceramah menjadi strategi utama dalam proses belajar sehingga mengabaikan ragam metode yang lain (Anurrahman, 2009, p. 47). Lebih lanjut Daniel Nuhamara mengungkapkan bahwa dengan metode ceramah, para peserta didik tidak dibiasakan diberi ruang yang lebih besar dalam pembelajaran, melainkan peserta didik menerima saja apa yang diberikan oleh guru (Nuhamara, 2009, p. 136). Hal tersebut disebabkan karena kurangnya pengetahuan guru-guru tentang metode mengajar yang dapat dikembangkan dengan demikian menyebabkan para peserta didik sangat jarang difasilitasi untuk belajar, sehingga proses belajar tidak efisien efektif, kelas menjadi pasif dan tidak meningkatkan kemampuan serta belajar mereka. Hal tersebut disebabkan karena peserta didik kurang dilibatkan secara aktif dalam proses belajar mengajar. Lebih lanjut Paulus Lie menjelaskan jika suasana kelas pasif maka efektivitas pengajaran hanya dapat di terima oleh dan diserap oleh murid $20 \%$, artinya ada $80 \%$ pengajaran yang tidak dapat diterima dengan baik hal ini disebabkan guru menerapkan metode mengajar yang salah tidak sesuai dengan konteks pengajaran (Kristianto, 2006, p. 2).

Alkitab menegaskan bahwa Yesus, Sang Guru yang agung telah memberikan teladan kebenaran secara sempurna kepada murid-muridNya. Yesus memahami murid- murid-Nya dan Yesus menggunakan metode-metode yang sempurna untuk mendidik mereka sehingga mereka bisa menangkap dengan baik ajaran Yesus, kemudian menerapkan dan mengajarkan bagi orang lain. Yesus mengenal semua orang secara pribadi dan Dia mengetahui sifat dan karakter para murid-Nya (Yohanes 2 : 24-25). Tuhan Yesus mengajarkan kepada manusia kebenaran sesuai dengan pengertian mereka (Markus 4 : 33). Hal inilah yang menyebabkan Yesus dikenal sebagai Guru yang mengubah manusia (Yoh 4 : 1-42) serta menjadi dasar yang kokoh bagi Pendidikan Agama Kristen (PAK) (Lebar, 2006, p. 75).

Karena itu, dalam penelitian ini penulis akan membahas implikasi metode mengajar bagi guru pendidikan agama Kristen dengan harapan metode mengajar guru dapat menciptakan proses interaksi belajar mengajar lebih kreatif dan menyenangkan bagi peserta didik.

\section{MOTODE DAN RUANG LINGKUP PENELITIAN}

Metode penelitian yang digunakan dalam penulisan penelitian ini adalah metode pendekatan deskriptif, yaitu metode dan prosedur penelitian yang bersifat Research Library yaitu penelitian yang dilakukan dengan cara menelusuri serta menelaahnya atau menelusuri sumber-sumber kepustakaan yang ada hubungannya dengan masalah yang ingin dipecahkan (Nazir, 1998, p. 111). Untuk memperoleh data yang berkaitan dengan pembahasan dalam penelitian ini penulis melakukan studi literatur, yaitu dengan melakukan pengkajian buku-buku, jurnal maupun artikel-artikel yang berkaitan dengan pokok pembahasan penelitian, dengan maksud sebagai bahan referensi. 


\section{PEMBAHASAN}

\section{METODE MENGAJAR DALAM ALKITAB}

Dalam PAK metode adalah suatu pelayanan, suatu pekerjaan yang aktif, yang dilakukan oleh seorang guru PAK bagi Tuhan dan bagi sesama manusia, supaya kedua pihak bisa bertemu satu sama lain (Homrighausen, 2009, p. 74). Metode senantiasa hanyalah jalan dan alat saja, bukan tujuan. Tidak boleh metode dipergunakan supaya mendapat hasil dan sukses secara duniawi, tetapi kita mempergunakan metode supaya menghasilkan iman, pengetahuan dan penuturan yang sejati dalam hidup peserta didik yang dilayani.

Berikut ini metode-metode mengajar dalam alkitab sebagai berikut:

\section{a. Metode Mengajar Dalam PL}

\section{Pertama, Metode Shema atau Penugasan(ulangan 6:4-9)}

Dalam PL umat Israel diperintahkan oleh Tuhan untuk mendidik anak-anaknya, dalam konteks PL tugas mendidik atau mengajar merupakan tanggung jawab orang tua dalam hal ini seorang ayah (Kristianto, 2006, p. 12). W.Stanley Heath mengatakan "שמעy " shema bukan suatu instruksi yang khusus bagi kaum Israel. Namun sebagai ketetapan Allah, שמע "shema tetap berlaku sebagai kewajiban“" (Heath, 2005, p. 30). Ada dua hal yang menjadi isi penugasan dari "שמע" "shema (1) kasihilah Tuhan Allah mu dengan segenap hatimu, (2) kasihilah sesamamu manusia seperti diri mu sendiri. Dengan demikian bertolak dari pendapat Paulus Lilik Kristianto dan W Stanley Heath terhadap shema di atas, penulis mengambil suatu kesimpulan bahwa metode“" שמע"Shema/penugasan merupakan tanggung jawab orang tua dalam mendidik peserta didiknya (anak) untuk menanamkan nilai-nilai kekristenan kepada anak sehingga anak bertumbuh di dalam pengalan akan Allah dan takut kepada Tuhan, karena mengingat isi dari "Shema tersebut adalah dua hal di atas yaitu mengasihi Allah dan takut kepada Allah YHWH. Mengingat pengajaran shema begitu penting, Tuhan Yesus juga pernah mengutip pengajaran shema dari kitab PL.

\section{Kedua, Metode Menghafal (Amsal 22,6;Yosua 1:8)}

Sekolah-sekolah formal Yahudi menggunakan metode hafalan. Anak laki-laki berumur 6 tahun sudah mempelajari huruf-huruf Ibrani. Pada umur 10 tahun mereka diharapkan sudah mampu membaca, dan merangkai kalimat PL dalam bahasa Ibrani. Setelah itu mereka melanjutkan sekolah Beth Talmud untuk mempelajari Taurat lisan yang terdiri dari Misyina(Berisi halakhah, peraturan hukum dan ajaran-ajaran beserat pembicaraan-pembicaraan panjang lebar.. Talmud, dan hagadah. Mereka yang lulus dari Beth Talmud inilah yang nantinya menjadi guru-guru di sekolah dasar Yahudi tingkat dasar (Kristianto, 2006, p. 12).

Dalam PL metode hafalan ini juga diterapkan oleh Musa maupun Yosua. Musa mengunakan metode hafalan saat pengajarannya, setiba dari gunung Sinai setelah menerima dua loh batu (10 Hukum Tuarat) תרה "tôrâh " Dalam bahasa ibrani dan vó bahasa yunani. Ada perbedaan pendapat tentang asal usul kata tora, tetapi dapat dipastikan ada kaitannya dengan kata kerja hora yang berarti memimpin, mengajar, mendidik, dan dapat juga diartikan sebagai pengajaran. (Yes 1:10 dan Hag 2:11-13). Perlu diketahui tora diberikan oleh Allah tetapi melalui perantara-perantara manusia misalnya Musa, para imam, para nabi atau hamba Tuhan (Yes 42:4) (Doglas, 2004, p. 451). Musa menyampaikan hukum tersebut di depan 
peserta didiknya (umat Israel) untuk menghafalkan kesepuluh hukum Taurat ( Kel 19-20:17) yang sekaligus merupakan materi dan kurikulum pengajarannya. Dengan tujuan pengajaran, agar bangsa tersebut memiliki rasa takut akan Tuhan dan mengenal Tuhan Allah Abraham, Ishak dan Yakub. Metode yang sama dipakai juga oleh Yosua saat memimpin bangsa Israel keluar dari tanah perbudakan (Mesir) dan saat di mana bangsa tersebut mau memasuki tanah Perjanjian (Kanaan) hal tersebut terlihat dalam Josua 1:8

Yosua mengingatkan kembali kepada peserta didiknya yang merupakan generasi setelah Musa untuk mengingat (menghafal) materi pengajaran yang telah diberikan dahulu oleh Musa kepada generasi sebelum mereka. Hal itu terlihat jelas dari kata "pelajarilah buku (Taurat) itu siang dan malam". Hal tersebut menunjukan kepada suatu pengajaran penting yang harus diterapkan oleh bangsa Israel dalam keluarga. Oleh karena itu pengajaran yang telah disampaikan oleh para nabi harus dihafalkan siang dan malam.

\section{Ketiga, Metode Bercerita(Ulangan 4:9)}

Dalam PL bangsa Israel memiliki satu tradisi yang disebut dengan tradisi lisan, dalam tradisi ini orang tua dituntut untuk menceritakan penyertaan dan perbuatan Tuhan kepada anakanak mereka. Oleh sebab itu jauh sebelum metode bercerita dipergunakan oleh pakar pendidikan sekuler maupun pendidikan Kristen metode tersebut telah diterapkan oleh bangsa Israel dalam pengajaran hal tersebut terlihat dalam ayat-ayat berikut: Ulangan 4:9 (BIS) "Perhatikanlah dan ingatlah baik-baik, supaya seumur hidupmu kamu tidak lupa apa yang sudah kamu saksikan sendiri. Ceritakanlah kepada anak-cucumu”

Dalam pengajaran di jaman PL metode bercerita yang diterapkan oleh guru (orang tua) kepada peserta didik (anak-anak) tentang suatu peristiwa-peristiwa bermakna dengan tujuan menceritakan dan mengajarkan kemuliaan, kemahakuasaan dan penyertaan Allah sebagai penguasa tunggal dan satu-satunya Allah di alam semesta. Sehingga apa yang telah didengar oleh peserta didik didik hal tersebut diingat dan diceritakan dari generasi ke generasi.

\section{b. Metode Mengajar Dalam PB}

Dalam kaitannya dengan proses pembelajaran di sekolah, sudah tentu tokoh utama yang harus diteladani oleh para guru PAK adalah Yesus Kristus, Sang Guru Agung (Pra Excellence). Yesus merupakan seorang Guru (Rabbi atau Rabboni) dan Pendidik (Didaskalos) yang sangat mencintai tugasNya (lih. Mat.23:8, Mrk.14:14,Luk.22:11, Yoh.3:2). Dengan jelas dan tegas Yesus mendukung murid-muridNya yang mengakui Dia sebagai Guru (Yoh 13:13-14, "Kamu menyebut Aku Guru dan Tuhan, dan katamu itu tepat, sebab memang Akulah Guru dan Tuhan”). Sebagai seorang guru, Ia mempergunakan metode pembelajaran yang aktif, kreatif dan variatif sehingga mampu menarik perhatian murid-murid dan para pendengarNya. Metode mengajar Yesus dapat digolongkan dalam beberapa bagian, yang akan penulis bahas pada bagian berikut.

\section{Metode Mengajar Tuhan Yesus}

Pertama, Metode Ceramah (Lecture Method). Dengan metode Ceramah Yesus berusaha menyampaikan pengetahuan kepada murid-muridNya atau menafsirkan pengetahuan tersebut. Boehlke menegaskan dengan metode ini, Yesus mengharapkan paling tidak dua respon 
dari pendengarNya, yaitu pengertian mendalam dan perilaku hidup baru. Secara sistematis, jelas dan tegas, Yesus menerangkan kepada murid-murid dan para pendengarNya tentang Kerajaan Allah, kebenaran dan kewaspadaan terhadap akal licik iblis yang selalu berusaha merusak iman mereka (lih. Mat. 5-7, Khotbah di Bukit. Mat. 24-25, Pengajaran di Bukit Zaitun). Melalui metode ceramah Yesus juga mengarakan serta memberikan bimbingan kepada murid-murid-Nya misalnya dalam Matius 10. Dari penggunaan metode ceramah para murid belajar secara tuntas, maka nanti mereka pun akan menjadi orang yang terdidik dan mendapat hak-hak Yesus sendiri (Mat 10:40-42) (Nuhamara, 2009, p. 139).

Kedua, Metode Menghafal (To learn by heart/Memories Method). Menurut Boehlke "tidak ada perintah khusus dari Tuhan Yesus agar murid-murid-Nya menghafal ayat tertentu dari kitab suci, namun kepentingannya jelas sekali bagi Yesus pribadi”. Setelah Yesus mengajarkan sesuatu, Yesus mengikhtiarkan isinya dalam suatu ucapan yang gampang dihafal, misalnya "..........Anak Manusia adalah Tuhan atas hari sabat" (Mat 12:8). "Bukan orang sehat yang memerlukan tabib, tetapi orang sakit” (Mat9:12), “..........Anak Manusia datang bukan untuk dilayani melainkan untuk melayani dan untuk memberikan nyawa-Nya menjadi tebusan bagi banyak orang” (Mrk 10:45) (Stevanus, 2009a, p. 10).

Ketiga, Metode Dialog. Metode mengajar Yesus sering dijumpai dalam Kitab Injil misalnya Mat 19:16-26, Yoh 4. Dengan metode ini Yesus mengajukan pertanyaan yang baru sebagai tanggapan atas pertanyaan yang diajukan kepada-Nya (Nuhamara, 2009, p. 11). Tuhan Yesus mengajak kepada pendengar untuk menggali lebih dalam lagi mengenai persoalan yang mendasar. Metode dialog yang Tuhan Yesus gunakan memainkan peran penting dalam peristiwa perjumpaan Yesus dengan wanita samaria. (Yohanes 4). Menurut Lois E Lebar pengunaan metode dialog pada peristiwa perjumpaan wanita samaria dengan Yesus menghasilkan beberapa pokok penting antara lain: "Yesus menimbulkan keingintahuan atas pertanyaan-pertanyaan. Yesus membangkitkan minat wanita samaria akan diri Yesus sebagai suatu Pribadi. Yesus memberikan kesempatan kepada wanita Samaria untuk menanggapi secara aktif setiap pertanyaan yang diajukan-Nya"(Lebar, 2006, p. 77).

Keempat, Metode Perjumpaan. Metode perjumpaan disebut juga metode mengajar yang memakai pertanyaan (Stevanus, 2009b, p. 1). Pertanyaan -pertanyaan yang Yesus berikan menantang para pendengarnya untuk berpikir lebih mendalam sebelum menjawab. Salah satu contoh metode perjumpaan yang digunakan Tuhan Yesus dapat dilihat dalam (lih Mat 16:15, Yohanes 5:1-18 ( kisah tentang orang buta di kolam Bethesda). Metode perjumpaan menuntut secara langsung kepada peserta didik untuk mengambil suatu Keputusan (Luk14:3. (Yoh 9:35)

Kelima, Metode Perbuatan Simbol. Pada awal pelayanan Yesus di depan umum, Yesus dibaptis oleh Yohanes Pembaptis. Yesus ingin mengajar kepada murid-muridNya melalui perbuatan simbolis ini. Menurut Daniel Stevanus dan Robert R Boehlke (Boehlke, 2011, p. 67) "Pertama, pelayanan-Nya berarti perlunya pengorbanan diri sebagai tujuan utama kehidupanNya, baptisan merupakan lambang kesengsaraan-Nya nanti. Kedua melalui lambang baptisan Yesus mengajarkan perlunya solider dengan semua orang lain dan bahwa solidaritas hanya dapat dinyatakan sebagai hamba yang merendahkan diri dan yang menderita".

Keenam Metode Perumpamaan (parables metod). Tuhan Yesus menggunakan metode perumpamaan-perumpamaan salah satu yang diungkapkan, dalam Matius 6:22-23 Yaitu tentang pelita Artinya "mata yang baik mencerminkan hati yang baik" mata yang jahat mencerminkan 
hati yang cemburu dan kikir Hal ini berarti, satu-satunya jalan untuk merubah sifat ini ialah meminta kepada Tuhan, supaya Ia mengeluarkan balok berarti (dosa, kesalahan) itu dari mata manusia, sehingga orang bisa dapat melihat lagi dengan terang, seperti Ia kehendaki.

\section{Metode Mengajar Rasul Paulus}

Pertama, Metode ceramah ( Kis 17:22-31). Salah satu bagian pengajaran yang paling terkenal oleh Rasul Paulus dapat dijumpai dalam Kis 17:16-34 (apologetika Paulus di Kota Athena). Dalam pengajarannya di kota Athena, Paulus menghadapi orang-orang yang berpendidikan khususnya filsafat, karena itu Paulus mengunakan metode ceramah dengan teknik apologetika. Dengan isi kurikulum yang Paulus beritakan di depan Areopagus adalah (Park, 2001, p. 254) (1) Allah menciptakan segala makhluk (Kis 17:24), (2) Allah yang mengatur segala makhluk di dunia (Kis 17:24), (3) Allah yang memberi hidup segala yang bernapas, (4) Allah hakim yang menghakimi segala makhluk oleh Yesus Kristus (Kis 17:31). Dari metode yang digunakan oleh Rasul Paulus pendengar dituntut untuk berpikir dan mengambil suatu kesimpulan dari isi pengajaran yang diberitakannya khususnya para ahli-ahli filsuf Yunani di kota Athena.

\section{Kedua, Metode Diskusi/Bertukar Pikiran (Kis 17:17)}

Metode diskusi yang Rasul Paulus gunakan dalam teks Kisah Para Rasul 17:17 masih merupakan rentetan dari pengajaran Rasul Paulus di Athena. Dalam konteks tersebut Paulus bertukar pikiran dengan filsuf golongan Epikuros dan Stoa yang mempunyai kedudukan istimewa di masyarakat mereka mahir dan cerdik berargumentasi. Yang menjadi sasaran dari pengajaran Rasul Paulus bukan saja berfokus pada para filsuf namun juga pengajaran Rasul Paulus ditujukan kepada masyarakat Athena pada umum itu dapat dibuktikan dengan pengajaran yang dilakukan di “ $\dot{\alpha} \gamma o \rho \alpha ́$ “ (ag-or-ah') Pasar bukan saja menjadi pusat perdagangan tetapi juga menjadi pusat urusan umum. Pasar dalam konteks Kis 17:17 digunakan sebagai tempat pemeriksaan perkara (Kis 16:19 band 19:38), juga sebagai tempat mengulas persoalan filsafat dan agama(Doglas, 2004, p. 204), itu berarti pengajaran Paulus saat berada di Athena dapat dikatakan mengemparkan seluruh Athena karena pengajarannya didengar oleh semua orang yang menuntut suatu pengakuan dan keputusan atas pengajaran yang disampaikannya.

\section{Ketiga, Metode Pengunaan Media (Kis 17:22, 18:1-5)}

Menurut Mimbrod Faod, Rasul Paulus menggunakan beberapa media atau sarana dalam melakukan pengajarannya baik di Athena dan juga di Korintus. Pengunaan media yang Rasul Paulus gunakan di Athena berupa (1) Bahasa Yunani, Tarsus terkenal dengan pusat pendidikan (Kis 21:39), Paulus telah mempelajari berbagai filsafat Yunani dari seorang Gamaliel, oleh karena itu Paulus telah menguasai benar bahasa Yunani. Dengan penguasaan bahasa yang dimiliki oleh Paulus, Paulus gunakan untuk memulai pengajarannya di hadapan para filsuf

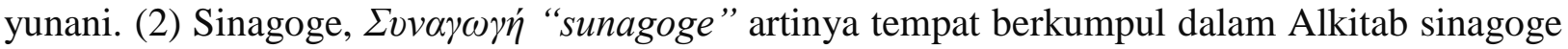
ialah sekumpulan sekelompok orang dari satu tempat untuk beribadah (Luk 12:11) di sinilah

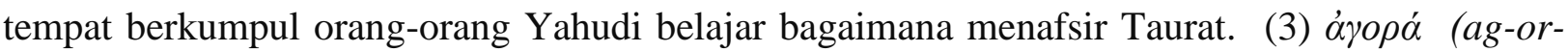
$\left.a h^{\prime}\right)$ Tempat kerja di pusat kota, bagi bangsa-bangsa lain pusat kota merupakan tempat orangorang mendengar pidato(Schnabel, 2010, p. 18), (4) ruang sidang Areopagus (4) tukang tenda (Kis 18:1-5). Melihat media pengajaran yang dipakai oleh Paulus, Paulus menggunakan media 
atau sarana tersebut sebagai mimbar memulai pengajaran dan pendengar merupakan peserta didiknya.

Sebagai dampak pengajaran Rasul Paulus di Athena penulis merumuskan dua tanggapan yang timbul di kalangan masyarakat Athena yaitu: Dampak Negatif (Kis17:16,34), Paulus

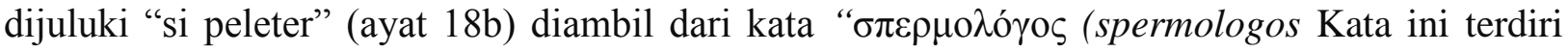
dari " $\sigma \pi \varepsilon \rho \mu \alpha$ " dan kata " $\lambda \varepsilon \gamma o$ " (mengangkat, memungut, mengumpulkan) spermonologos (1) dikenakan pada burung yang mematuk beni sana-sini (2) kepada orang yang mengumpulkan barang rongsokan/loak di pasar. Sebagian pendengar menganggap Paulus seorang intelektual dan filsafat murahan dan pemberita dewa asing (ayat 18c). Dampak negatif ini muncul dari kaum Epikuros yang menolak pengajaran Paulus tentang "kebangkitan orang mati" hal ini disebabkan karena menurut aliran ini kematian adalah akhir dari segala-galanya. Dampak Positif (Kis17:34) sikap positif datang dari Dionisius salah seorang anggota Areopagus dan seorang wanita yang bernama Damaris.

Metode Bimbingan. Metode bimbingan Rasul Paulus dapat dijumpai dalam 13 surat kiriman Rasul Paulus beberapa di antaranya, $1 \& 2$ Timotius, Titus, Filemon, Yakobus, $1 \& 2$ Tesalonika. Dalam surat-surat tersebut Paulus memberikan suatu metode pengajaran yang bersifat bimbingan,(Boehlke, 1991, p. 73) walaupun setiap kitab memiliki konteks dan latar belakang budaya yang berbeda namun metode pengajaran yang disampaikan oleh Paulus sebagian besar memiliki kesamaan (menggunakan metode bimbingan) contohnya (1 Tes 2:1112., 2 Tes 3:6c, Titus 1:9, 1 Timotius 4:12, 2Tim1:1, 3:15c.

Dari ayat-ayat tersebut Paulus memiliki satu tujuan pengajaran melalui metode bimbingan yaitu menuntun peserta didik (jemaat-jemaat) untuk memperoleh pengertian yang benar tentang pokok-pokok iman Kristen yang dapat diaplikasikan dalam kehidupan mereka, sehingga peserta didik bertumbuh dalam pengenalan akan Kristus Yesus.

\section{IMPLIKASI METODE MENGAJAR PENDIDIKAN AGAMA KRISTEN}

\section{A. Menuntun Peserta Didik untuk Memperoleh Pengetahuan yang dalam tentang Pokok -Pokok Iman Kristen}

Belajar dari sang Guru Agung mengajar merupakan suatu tugas penting dan mendasar dari seluruh pelayanan Tuhan Yesus. Dalam injil-injil synopsis Yesus dipanggil $\dot{\rho} \alpha \beta \beta i$ rhabbi (Yoh 3:2, Mat 9:11,Yoh 11:28, 20:16) ini menunjukan suatu indikasi bahwa Yesus merupakan guru yang disegani (Yoh 3:3, pengakuan Nikodemus sang ahli taurat) dan sekaligus guru yang kontroversi di kalangan orang farisi dan ahli Taurat dalam hal pengajaran-Nya. Dari setiap pengajaran, Yesus memiliki suatu tujuan pengajaran yang sistematis, terarah, kurikulum yang jelas serta metode yang sesuai dengan konteks pengajaran (siapa yang diajar), hal ini terlihat pada tiga contoh pendekatan pengajaran serta metode mengajar yang dipakai oleh Tuhan Yesus saat mengajar perempuan samaria (Yoh 4:1-42), Nikodemus (Yoh 3:1-22), dan orang buta (Mat 9:27-34, Mrk 8:22-26, Yoh 9, Mat 20:29-34, Mrk 10:46-52, Luk 18:35-43) (Lebar, 2006, p. 89).

Pertama, perempuan Samaria. Metode yang digunakan Tuhan Yesus dalam mengajar perempuan Samaria adalah metode pengunaan sarana (sumur Yakub). Yesus menuntun perempuan Samaria kepada satu kebutuhan mendasar lebih dari kebutuhan jasmanianya yaitu keselamatan jiwa. Dalam percakapan Tuhan Yesus dan perempuan samaria Tuhan Yesus mengalihkan suatu perbincangan tentang kebutuhan yang bersifat jasmaniah kepada suatu kebutuhan rohani. Tuhan Yesus tahu bahwa perempuan samaria membutuhakan air hidup (Yesus sendiri) dari pada air yang sifatnya secara jasmani. Namun hal tersebut diawali dari 
metode mengajar yang relevan sesuai dengan kebutuhan peserta didik-Nya (perempuan Samaria). Dengan isi kurikulum pengajaran sebagai berikut: (1) Soteriologi (Yoh 13-15), (2) Karunia Allah (Yoh 4:10), (3) Etika (17-18), (4) Kristologi (24-26), (5) Iman (4:2).

Kedua, Nikodemus, antara perempuan Samaria dan Nikodemus ada perbedaan yang jelas. Perempuan Samaria dapat digolongkan komunitas masyarakat yang terbuang, berasal dari ras campuran yang dipandang rendah sedangkan Nikodemus pemimpin Yahudi yang terpandang, intelektual, dan memiliki tradisi keagamaan yang radikal. Metode mengajar yang digunakan Tuhan Yesus pun berbeda, dalam konteks Nikodemus Tuhan Yesus mengunakan metode mengajar diskusi atau tanya jawab, dengan isi kurikulum sebagai berikut: (1) kelahiran kembali (Yoh 3:3-7), (2) soteriologi (Yoh 3:15-18), (3) iman (Yoh 3:18).

Ketiga, orang-orang buta. Peserta didik yang ketiga yang diajar oleh Tuhan Yesus adalah orang buta, yang menarik dari peserta didik yang ketiga adalah seluruh peserta didik memiliki cacat fisik (buta), dan metode yang digunakan oleh Tuhan Yesus dalam mengajar peserta didik yang ketiga adalah metode pengunaan sarana, Yesus menggunakan sarana mengajar sederhana yang tidaklah rumit dan mudah didapat (tanah). Yesus menggunakan media atau saran sebagai mimbar memulai pengajarana-Nya dengan isi kurikulum mengajar para orang buta sebagai berikut: (1) iman (Matius 9:27-38), (2) Pengetahuan tentang Allah (Markus 8:22-26), (3) pengetahuan tentang karya-Nya (Yoh pasal 9).

Dengan demikian mengacu pada tiga metode mengajar di atas serta isi dari kurikulum pengajaran yang digunakan oleh Tuhan Yesus penulis dapat menyimpulkan bahwa, cara mengajar Tuhan Yesus serta penggunaan metode dari tiga peserta didik di atas memiliki peran yang berbeda-beda. Namun dalam konteks pengajaran Tuhan Yesus di atas, Tuhan Yesus memiliki tujuan yang jelas dalam mengajar serta metode yang digunakan ialah menuntun peserta didik-Nya untuk memperoleh pengetahuan yang dalam tentang pokok-pokok iman Kristen, pokok-pokok tersebut dapat dilihat dari isi kurikulum yang Tuhan Yesus gunakan dari tiga peserta didik yang berbeda yaitu:

Pertama, Iman, seorang guru PAK dalam proses pembelajaran dituntut untuk memberikan pengajaran mendalam tentang iman Kristen yaitu iman yang berkaitan dengan soteriologi kepada Tuhan Yesus Kristus, sehingga pembelajaran PAK bukan hanya mentrasferkan ilmu kepada anak peserta didik, tetapi pembelajaran PAK juga merupakan suatu proses pentransferan doktrin kekristenan sehingga peserta didik memiliki kepercayaan (faith) yang kokoh, dan percaya Yesus Kristus sebagai Tuhan dan Juruselamat pribadi, karena muatan dan penyelenggaraan PAK tidaklah sama dengan pendidikan sekuler oleh karena itu esensi dan pesan PAK harus diterima dengan baik oleh peserta didik. Alkitab secara tegas berkata "jika iman tidak disertai dengan perbuatan pada hakikatnya adalah mati (Yak 2:17)" artinya Allah yang menanamkan, memberi iman kepada peserta didik dari sejak kekekalan namun iman harus diwujudkan dalam kehidupan sehari-hari yaitu di dalam proses belajar mengajar sehingga iman itu dapat betumbuh inilah yang menjadi tugas dari seorang guru PAK.

Kedua, Soteriologi atau Keselamatan, metode bukan hanya suatu jalan atau cara tetapi lebih dari itu metode adalah sarana pemberitaan Injil dalam proses belajar mengajar. Dari tiga tipe peserta didik yang telah penulis sampaikan pada bagian sebelumnya metode pengajaran Yesus berujung pada suatu penuntunan kepada peserta didik untuk memperoleh keselamatan di dalam diri-Nya. Yesus menempatkan metode sebagai sarana bukan tujuan, ini juga yang menjadi pengajaran penting bagi guru PAK menempatkan metode mengajar sebagai bagian terpenting namun 
metode bukanlah tujuan dari pengajaran PAK. Tetapi metode merupakan sarana untuk menuntun peserta didik memperoleh keselamatan jiwa.

Ketiga, Pengetahuan tentang Allah, sebagaimana shema Israel menekankan suatu konsep mengasihi Allah dan pengetahuan akan Allah, hal ini juga penulis menganggap pesan penting dalam pengajaran PAK. Seorang guru PAK memiliki peran yang penting dalam penyampaian PAK, salah satunya yaitu guru menuntun peserta didik untuk memiliki pengetahuan yang benar tentang Allah, namun guru juga dituntut terlebih dahulu memiliki konsep yang benar tentang pengetahuan Allah. Sehingga, guru tidak salah menanamkan konsep yang benar tentang Allah, karena setiap agama memiliki konsep yang berbeda-berbeda tentang Allah. Hal tersebut dapat dilihat dalam pengajaran Tuhan Yesus kepada orang buta dalam Yohanes 9, Yesus memberikan pengajaran dengan konsep pengenalan yang benar. Paulus Lie berpendapat "metode akan membantu guru untuk membawa anak-anak pada pertumbuhan rohani yang mendalam"(Lie, 2002, p. 3). Oleh karena itu dalam proses belajar mengajar PAK metode memainkan peran yang penting yaitu menuntun peserta didik mengerti dan mengetahui Allah transenden dan juga Allah itu imanen yang diwujudkan dalam diri Yesus Kristus.

Dengan demikian penulis dapat menyimpulkan bahwa dalam menanamkan nilai-nilai dan prinsip iman Kristen kepada peserta didik baik dalam lingkungan keluarga, gereja, masyarakat dan lingkungan pendidikan formal atau non formal metode memainkan peranan yang penting karena baik pendidikan sekuler maupun pendidikan Kristen, baik gereja dan masyarakat pasti menggunakan salah satu metode apapun nama dan bentuk dari metode tersebut. Metode memiliki peranan yang penting dalam pengajaran PAK, metode sebagai sarana menuntun peserta didik mengenal dan memahami prinsip-prinsip iman Kristen dalam proses belajar mengajar. Oleh karena itu sebagai seorang guru baik guru PAK maupun guru umum hendaknya menggunakan metode dalam mengajar karena metode juga memiliki andil yang penting dalam kegiatan belajar mengajar.

\section{B. Menciptakan Proses Belajar dan Mengajar yang Berkualitas}

Guru merupakan unsur penting dalam kegiatan belajar mengajar. Hal ini sangat beralasan karena, seperti yang di kemukakan oleh Brian Hill "gurulah yang membimbing peserta didik untuk belajar mengenal, memahami, dan menghadapi dunia tempatnya berada". Dengan demikian panggilan terpenting bagi seorang guru dalam menjalankan tugas mengajarnya ialah mendorong peserta didik untuk menimba pengetahuan, pemahaman, serta membimbing peserta didiknya untuk memperoleh pengertian mendalam terhadap pokok-pokok iman Kristen sehingga bermanfaat bagi peserta didik dalam konteks pendidikan agama kristen. Pullias dan Young mengemukakan bahwa "dalam melaksanakan tugasnya seorang guru adalah pembimbing, pendidik, pembaharu, teladan hidup, pencari gagasan baru, penasehat, pemegang otoritas, dan pengilham cita-cita" (Lie, 2002, p. 68). Oleh karena itu hal ini dapat terealisasi dengan baik dalam proses pembelajaran dan guru dapat menciptakan proses belajar yang berkualitas jika guru memahami dengan benar tugas dan tanggung jawabnya serta menerapkan beragam metode dalam proses belajar mengajar dan tidak berfokus guru sebagai sumber informasi, tetapi melibatkan siswa dalam interaksi pembelajaran dan guru memiliki kompetensi sesuai dengan bidangnya. Walaupun metode memiliki peranan untuk menciptakan proses belajar mengajar yang berkualitas namun harus dibarengi dengan kompetensi guru karena kedua hal ini mendukung satu dengan yang lain, karena perlu diingat walaupun guru PAK memiliki 
kompetensi dibidangnya tetapi jika tidak pandai dalam menggunakan metode dalam belajar mengajar maka proses belajar mengajar akan menjadi tidak berarti dan membosankan.

Dengan demikian kualitas pembelajara dapat dinilai dan diukur dengan cara sejauh mana guru mendesain pembelajaran dan pengelolaan kelas sehingga membuat peserta didik tertarik dan termotivasi dalam belajar dengan metode yang digunakan guru sehingga peserta didik tidak menjadi bosan dalam belajar. Oleh karena itu guru harus pandai menggunakan metode dalam interaksi pembelajaran, jika guru cakap dalam menggunakan metode maka dapat menciptakan pembelajaran yang berkualitas karena baik guru maupun peserta didik terlibat dalam kegiatan belajar mengajar.

\section{Menciptakan Suasana Kelas yang Partisipatif dan Aktif.}

Menurut Kamus Besar Bahasa Indonesia kata dasar dari Partisipatif adalah partisipasi yang memiliki arti hal ikut serta dalam suatu kegiatan, sedangkan aktif memiliki arti giat bekerja, giat berusaha, mampu bereaksi dan beraksi. Vernon A Magnesen Mengemukakan bahwa "manusia belajar 10\% dari apa yang kita baca, 20\% dari apa yang kita dengar, 30\% dari apa yang kita lihat, 50\% dari apa yang dilihat dan dengar, 70\% dari apa yang dikatakan, dan $90 \%$ dari apa yang dikatakan dan lakukan" (Sidjabad, 2017, p. 240). Sementara Paulus Lie mengemukakan " $80 \%$ pelajaran akan diserap dengan baik oleh anak jika anak dan guru terlibat aktif dalam mengajar." (Lie, 2002, p. 3) Salah satu kelemahan kerapkali yang dilakukan oleh guru adalah kurang melibatkan peserta didiknya dalam mengajar sehingga membuat suasana pembelajaran menjadi kaku dan fakum, sehingga peserta didik tidak memperoleh pengetahuan yang mendalam dalam proses belajar mengajar.

B.S.Sijabat menyatakan bahwa "diantara Yesus dan murid-murid-Nya (kelompok dua belas, tujuh puluh, serta kelompok orang yang datang dan pergi) senantiasa terjadi dialogis. Tuhan Yesus Tidak hanya menggunakan dan membangun komunikasi satu arah, tetapi juga dua arah" (Sidjabad, 2017, p. 236). Tuhan Yesus selalu menggunakan metode dalam pengajarannya sehingga dari metode yang digunakan oleh Tuhan Yesus serta pengajaran yang disampaikanNya memberi kesempatan kepada peserta didik-Nya untuk terlibat dalam proses belajar mengajar sehingga peserta didik-Nya ikut berpartisipasi dan aktif secara langsung dalam mengikuti penyampaian pelajaran-Nya, (hal ini dapat dilihat dalam Injil Yohanes 3:1-21, 4:142).

Dari tiga pernyataan di atas, interaksi proses belajar mengajar dapat berjalan dengan baik diawali dari metode apa yang dipakai oleh seorang guru dalam mengajar, metode ikut ambil bagian dari terjadinya suatu interaksi pembelajaran. Perlu diingat metode yang digunakan guru dalam mengajar harus sesuai dengan kondisi materi pelajaran, dan kesiapan peserta didik dalam menerima materi yang hendak disampaikan oleh guru dalam belajar.

\section{KESIMPULAN}

Salah satu tujuan umum pemerintah menyelengarakan pendidikan nasional adalah mencerdaskan bangsa, sehingga dapat menghasilkan manusia yang memiliki intelektual, karakter, serta bermoral. Pendidikan Agama Kristen adalah bagian dari penyelenggaraan pendidikan tersebut. Segala upaya telah dilakukan pemerintah mulai dari penyempurnaan kurikulum sampai kepada pengadaan sarana prasarana, bahkan mendesain media-media pembelajaran yang efektif, hal tersebut guna menunjang program pemerintah di atas. Namun, 
masih mengalami berbagai kendala dalam pelaksanaannya sehingga membuat tujuan mencerdaskan bangsa belum terlaksana dengan baik.

Salah satu kendala yang sering dihadapi oleh guru baik guru sekuler maupun guru Kristen dalam proses pembelajaran adalah masalah metode dalam mengajar. Hal ini dikarenakan kurangnya pengetahuan guru tentang metode dalam mengajar. Oleh karena itu mengutip pendapat dari B.S.Sijabat, menjelaskan metode adalah cara atau prosedur dalam mengelola interaksi antara guru dan peserta didiknya bagi berlangsungnya peristiwa belajar.

Namun, kecenderungan pendidikan masa kini masih mengadopsi proses pembelajaran guru sebagai sumber belajar. Guru kurang melibatkan peserta didik dalam interaksi pembelajaran sehingga menyebabkan kurangnya motivasi atau minat dari peserta didik untuk belajar, rendahnya hasil belajar siswa, proses pembelajaran menjadi kaku, guru menjadi kurang kreatif dalam menyampaikan materi pelajaran, peserta didik menjadi bosan dalam belajar, serta munculnya kejenuhan dalam dalam diri peserta didik. Hal tersebut disebabkan karena guru belum memahami beragam metode, serta peranan dari metode dalam mengajar.

Paulus Lie menyatakan jika guru tidak kreatif dalam mengajar maka pembelajaran yang di terima oleh peserta didik hanya $20 \%$ sedangkan $80 \%$ tidak diterima dengan baik oleh peserta didik, hal tersebut membuat peserta didik dirugikan. Oleh karena itu sebagai seorang guru dituntut lebih bertanggung jawab, dan kreatif dalam mengajarnya yang diwujudkan dalam tindakan mengajarnya. Seorang guru yang kreatif tidak menetapkan dan menggunakan satu atau dua metode dalam mengajar namun guru yang kreatif menerapkan beragam metode dalam proses belajar mengajar, dengan tujuan agar materi pembelajaran dapat diterima dengan baik oleh setiap peserta didik.

Oleh karena itu belajar dari Guru Agung, Yesus memberikan teladan dalam interaksi belajar mengajar. Hal tersebut dapat dilihat dalam beberapa ayat berikut Matius 5: 1-16, Yohanes 3:1-21, Yohanes 4:1-42. Dari ayat-ayat tersebut dapat dilihat Yesus mengajar dengan menggunakan beragam metode sehingga menghasilkan suatu pengajaran dan Keputusan dari peserta didik-Nya. Yesus memiliki suatu tujuan dalam pengajaran dengan metode yang digunakan-Nya yaitu menuntun peserta didik-Nya mengenal dan memahami pokok-pokok penting dari iman Kristen.

Oleh karena itu seorang guru PAK harus memahami beberapa peranan metode dalam mengajar yaitu: (1) menuntun peserta didik untuk memperoleh pengetahuan yang dalam tentang pokok-pokok iman Kristen, (2) menciptakan proses belajar mengajar yang lebih berkualitas, (3) menciptakan suasanaa kelas yang partisipatif dan aktif, (4) sebagai alat motivasi, (5) sebagai alat mencapai tujuan pengajaran, dan (6) sebagai alat evaluasi pengajaran.

Dengan demikian jika guru PAK sudah memahami peranan metode dalam mengajar maka guru dan peserta didik dapat menciptakan suatu proses pembelajaran partisipatif, kreatif dan menyenangkan, sehingga dapat menimbulkan motivasi peserta didik untuk belajar, mengetahui, dan menerapkan prinsip serta nilai-nilai dari iman Kristen. 


\section{DAFTAR PUSTAKA}

Anurrahman. (2009). Belajar dan Pembelajaran. Alfabeta.

Boehlke, R. R. (1991). Sejarah Perkembangan Pemikiran dan Praktek Pendidikan Agama Kristen. BPK Gunung Mulia.

Boehlke, R. R. (2011). Sejarah Perkembangan Pikiran dan Praktek Pendidikan Agama Kristen dari Plato sampai IG Loyola. BPK Gunung Mulia.

Doglas, D. (2004). Ensiklopedia Alkitab Masa Kini Jilid II. Yayasan Komunikasi Bina Kasih.

Heath, W. S. (2005). Teologi Pendidikan Amak Dasar Pelayanan kepada anak. Kalam Hidup.

Homrighausen, I. H. E. \& E. G. (2009). Pendidikan Agama Kristen. BPK Gunung Mulia.

Kristianto, P. L. (2006). Prinsip dan Praktik Pendidikan Agama Kristen. Andi Offset.

Lebar, L. E. (2006). Education that is Christian. Gandum Mas.

Lie, P. (2002). Metode anak aktif dalam bercerita dan membaca Alkitab. Andi Offset.

Nazir, M. (1998). Metode Penelitian. Gnalia Indonesia.

Nuhamara, D. (2009). Pembimbing PAK. Jurnal Indo Media.

Park, Y. S. (2001). Tafsiran Alkitab Kisah Para Rasul. Departemen Literatur YPPII.

Schnabel, E. J. (2010). Rasul Paulus Sang Misionaris. Andi Offset.

Sidjabad, B. S. (2017). Mengajar Secara Profesional (3rd ed.). Kalam Hidup.

Sidjabat, B. S. (1993). Mengajar secara Profesional Mewujudkan Visi Guru Profesional. Bandung: Kalam Hidup.

Sijabat, B. S. (1994). Strategi Pendidikan Kristen: Suatu Tinjauan Theologis-Filosofis. Yogyakarta: Yayasan Andi.

Somandi, S. N. \&. (2012). Panduan Penyusunan Silabus dan RPP. Group Relasi Inti.

Stevanus, D. (2009a). Sejarah PAK dan Toko-toko Besar PAK. Bina Media Info.

Stevanus, D. (2009b). Sejarah PAK Toko-toko Besar PAK. Bina Media Infi.

Zain, A. (2006). Strategi Belajar Mengajar. Rineke Cipta. 